\title{
Low LET Irradiations of Uranyl Sulfate Solutions in the Absence and Presence of $\mathrm{Fe}^{+2}$ and $\mathrm{Fe}^{+3}$ lons
}

Chemical and Fuel Cycle Technologies Division 


\begin{abstract}
About Argonne National Laboratory
Argonne is a U.S. Department of Energy laboratory managed by UChicago Argonne, LLC under contract DE-AC02-06CH11357. The Laboratory's main facility is outside Chicago, at 9700 South Cass Avenue, Lemont, Illinois 60439. For information about Argonne and its pioneering science and technology programs, see www.anl.gov.
\end{abstract}

\title{
DOCUMENT AVAILABILITY
}

Online Access: U.S. Department of Energy (DOE) reports produced after 1991 and a growing number of pre-1991 documents are available free at OSTI.GOV (http://www.osti.gov/),

a service of the US Dept. of Energy's Office of Scientific and Technical Information.

Reports not in digital format may be purchased by the public from the National Technical Information Service (NTIS):

U.S. Department of Commerce

National Technical Information Service

5301 Shawnee Road

Alexandria, VA 22312

www.ntis.gov

Phone: (800) 553-NTIS (6847) or (703) 605-6000

Fax: (703) 605-6900

Email: orders@ntis.gov

Reports not in digital format are available to DOE and DOE contractors from the Office of Scientific and Technical Information (OSTI):

U.S. Department of Energy

Office of Scientific and Technical Information

P.O. Box 62

Oak Ridge, TN 37831-0062

www.osti.gov

Phone: (865) 576-8401

Fax: (865) 576-5728

Email: reports@osti.gov

\section{Disclaimer}

This report was prepared as an account of work sponsored by an agency of the United States Government. Neither the United States Government nor any agency thereof, nor UChicago Argonne, LLC, nor any of their employees or officers, makes any warranty, express or implied, or assumes any legal liability or responsibility for the accuracy, completeness, or usefulness of any information, apparatus,

product, or process disclosed, or represents that its use would not infringe privately owned rights. Reference herein to any specific commercial product, process, or service by trade name, trademark, manufacturer, or otherwise, does not necessarily constitute or imply its endorsement, recommendation, or favoring by the United States Government or any agency thereof. The views and opinions of document authors expressed herein do not necessarily state or reflect those of the United States Government or any agency thereof, Argonne National Laboratory, or UChicago Argonne, LLC. 
ANL-19/44

\section{Low LET Irradiations of Uranyl Sulfate Solutions in the Absence and Presence of $\mathrm{Fe}^{+2}$ and $\mathrm{Fe}^{+3}$ lons}

by

Michael Kalensky, Thomas Brossard, and Peter Tkac

Chemical and Fuel Cycle Technologies Division, Argonne National Laboratory

Kevin J. Quigley and Sergey D. Chemerisov

Experimental Operations and Facilities, Argonne National Laboratory

September 20, 2019 



\section{CONTENTS}

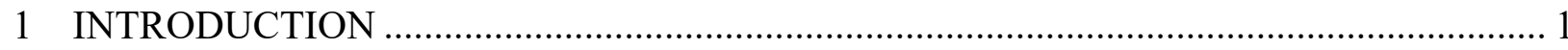

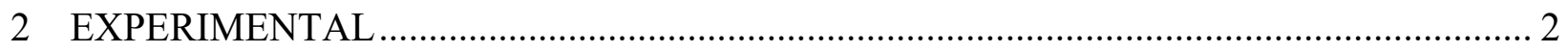

2.1 Preparation of Uranyl Sulfate Solutions …………................................................. 2

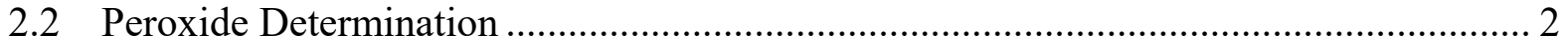

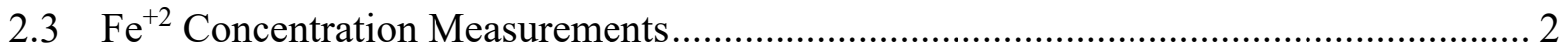

2.4 Van de Graaff Operation and Oxalic Acid Dosimetry................................................... 3

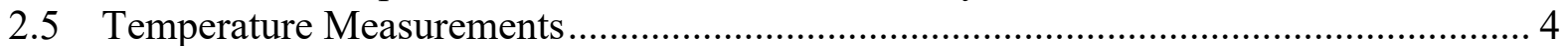

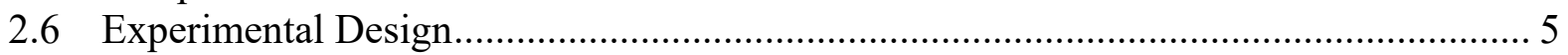

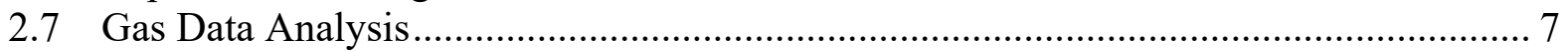

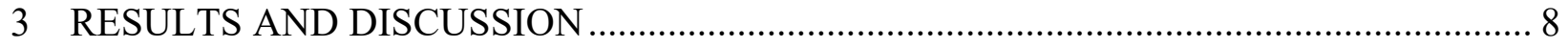

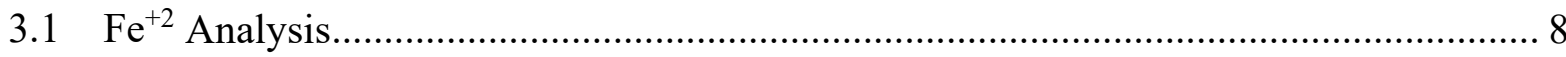

3.2 Irradiations to Determine the Experimental Parameters for Precipitation ........................ 8

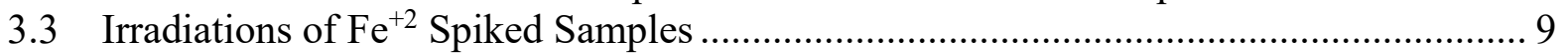

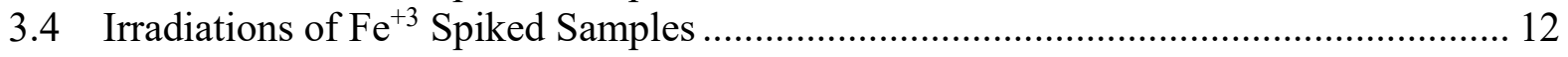

3.5 Summary of Ratios of Iron Oxidation States .............................................................. 14

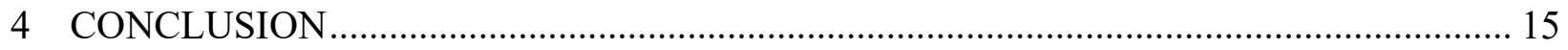

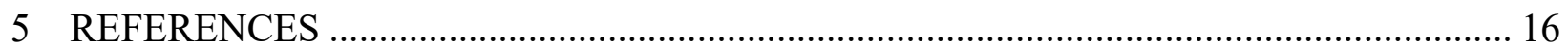

\section{FIGURES}

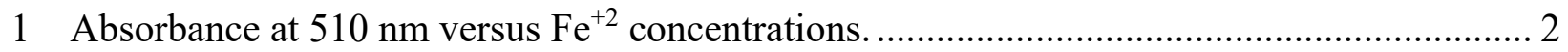

2 Dependence of dose vs. Van de Graaff irradiation parameters for a $1.0 \mathrm{~mL}$ sample. .............. 4

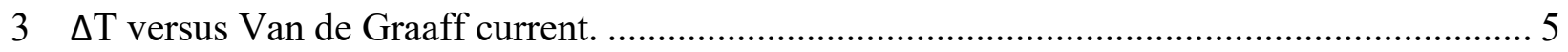

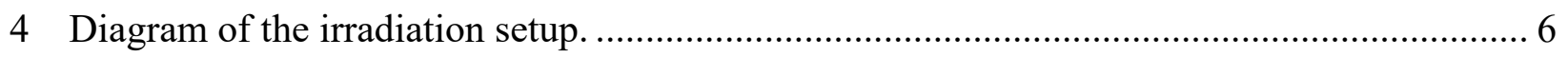

5 Photograph of the irradiation setup at the Van de Graaff accelerator facility.......................... 6

6 Irradiated LEU sample containing $\mathrm{U}$ precipitate and containing no $\mathrm{U}$ precipitate................... 9

7 Peroxide test of un-spiked sample from 7/2/19, 240 minute irradiation at

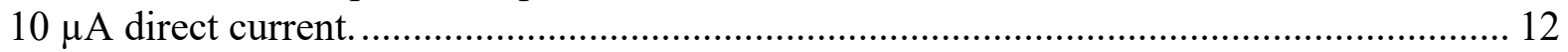

8 Peroxide test of $\mathrm{Fe}^{+2}$ spiked sample from 7/18/19, 240 minute irradiation at $10 \mu \mathrm{A}$............ 12 


\section{TABLES}

1 LEU Solution ICP-MS analysis. *Fe analyzed using the phenanthroline method................ 8

2 Irradiation parameters and analysis data for LEU samples without added Fe spike ............ 10

3 Irradiation parameters and analysis data for LEU samples with added $\mathrm{Fe}^{+2}$ spike.............. 11

4 Irradiation parameters and analysis data for LEU samples with added $\mathrm{Fe}^{+3}$ spike.............. 13

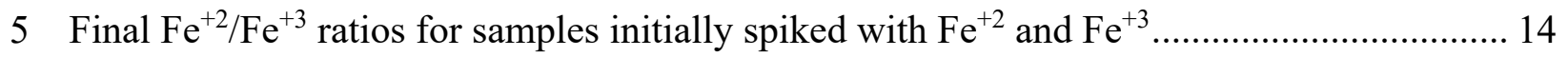




\section{INTRODUCTION}

Argonne National Laboratory (Argonne) is assisting one of the potential domestic Mo-99 producers, SHINE Medical Technologies, as part of the National Nuclear Security Administration's (NNSA) Office of Material, Management, and Minimization $\left(\mathrm{M}^{3}\right)$ program in the development of a domestic Mo-99 production pathway that does not use highly enriched uranium (HEU). The process proposed by SHINE would produce Mo- 99 by neutron-induced fission of a low enriched uranium (LEU) solution as uranyl sulfate in a subcritical assembly.

One potential technical difficulty with using uranyl sulfate is possible precipitation of uranyl peroxide $\left(\mathrm{UO}_{2} \mathrm{O}_{2} \cdot \mathrm{nH}_{2} \mathrm{O}\right.$ or $\left.\mathrm{UO}_{4} \cdot \mathrm{nH}_{2} \mathrm{O}\right)$. Through a series of reactions, hydrogen peroxide is generated in solution by the radiolysis of water, which can react with the uranyl ion to form uranyl peroxide, thus forming a precipitate [1-5]. Uranyl-peroxide precipitation must be avoided for safe production of Mo-99 during the proposed process. Equation 1 shows the reaction of uranium and hydrogen peroxide in solution to form the precipitate:

$$
\mathrm{UO}_{2}{ }^{2+}+\mathrm{H}_{2} \mathrm{O}_{2}+\mathrm{nH}_{2} \mathrm{O} \leftrightarrow \downarrow \mathrm{UO}_{2} \mathrm{O}_{2} \cdot \mathrm{nH}_{2} \mathrm{O}(\mathrm{s})+2 \mathrm{H}^{+}
$$

Previous experiments [4] showed that uranyl peroxide was decomposed by high temperatures and radiolysis. Two mechanisms have been proposed by Silverman et al. for the destruction of uranyl peroxide, See Equations 2, 3, 4, and 5 [6].

$$
\begin{gathered}
\mathrm{UO}_{2} \mathrm{O}_{2} \cdot 2 \mathrm{H}_{2} \mathrm{O}(\mathrm{s})+2 \mathrm{H}^{+} \rightarrow \mathrm{UO}_{2}{ }^{2+}+\mathrm{H}_{2} \mathrm{O}_{2} \\
\mathrm{H}_{2} \mathrm{O}_{2} \rightarrow \mathrm{H}_{2} \mathrm{O}+1 / 2 \mathrm{O}_{2} \\
\mathrm{UO}_{2} \mathrm{O}_{2} \rightarrow \mathrm{UO}_{3}+1 / 2 \mathrm{O}_{2} \\
\mathrm{UO}_{3}+2 \mathrm{H}^{+} \rightarrow \mathrm{UO}_{2}{ }^{2+}+\mathrm{H}_{2} \mathrm{O}
\end{gathered}
$$

These experiments also showed that precipitation could be prevented by the addition of a metal ion such as iron. A series of irradiation experiments were performed using a $3 \mathrm{MeV}$ Van de Graaff accelerator to generate high radiation doses in $1 \mathrm{~mL}$ LEU uranyl-sulfate solutions at $\sim 190$ and $194 \mathrm{~g} / \mathrm{L}(19.8 \% \mathrm{U}-235)$. The purpose of these experiments was to examine whether $\mathrm{Fe}^{+2}$ or $\mathrm{Fe}^{+3}$ were equally effective at preventing precipitation of uranyl peroxide and determine the oxidation state of iron after an irradiation. 


\section{EXPERIMENTAL}

\subsection{PREPARATION OF URANYL SULFATE SOLUTIONS}

Uranium metal was oxidized to $\mathrm{U}_{3} \mathrm{O}_{8}$ and dissolved in a mixture of hydrogen peroxide and sulfuric acid with heat [5].

\subsection{PEROXIDE DETERMINATION}

Although it was possible to identify the presence of peroxide using the peroxide indicator strips (QUANTOFIX ${ }^{\circledR}$ peroxide test strips), which in colorless solution turn into different shades of blue; in highly colored yellow uranium solution, the concentration range of peroxide is difficult to identify due to a change of the color of indicator strips to green. Two types of test strips were used in the test with concentration limits of $25 \mathrm{ppm}$ and $100 \mathrm{ppm}$.

\section{$2.3 \mathrm{Fe}^{+2}$ CONCENTRATION MEASUREMENTS}

Samples were analyzed for $\mathrm{Fe}^{+2}$ content using the 1,10-phenanthroline method [7]. In this method, $\mathrm{Fe}^{+2}$ reacts with phenanthroline at a $\mathrm{pH} 3.2-3.3$, where three molecules of phenanthroline chelate each atom of ferrous iron $\left(\mathrm{Fe}^{+2}\right)$, to form an orange-red complex with a peak absorbance at $510 \mathrm{~nm}$. Color is independent in the $\mathrm{pH}$ range from 3-9, but $\mathrm{pH}=3$ gives rapid color development in the presence of excess phenanthroline. Color solutions are stable for up to six months. An aliquot of the irradiated LEU solution (50-200 $\mathrm{mg}$ ) was contacted with an excess of phenanthroline in the presence of ammonium acetate buffer. The colored solutions were measured on a Cary $5000 \mathrm{UV}$-Vis spectrophotometer. It is assumed that any iron not in the +2 oxidation state was present as +3 . Samples were analyzed several days to weeks after irradiation. Figure 1 shows the standard calibration curve of the colorimetric method for detection of $\mathrm{Fe}^{+2}$ concentration.

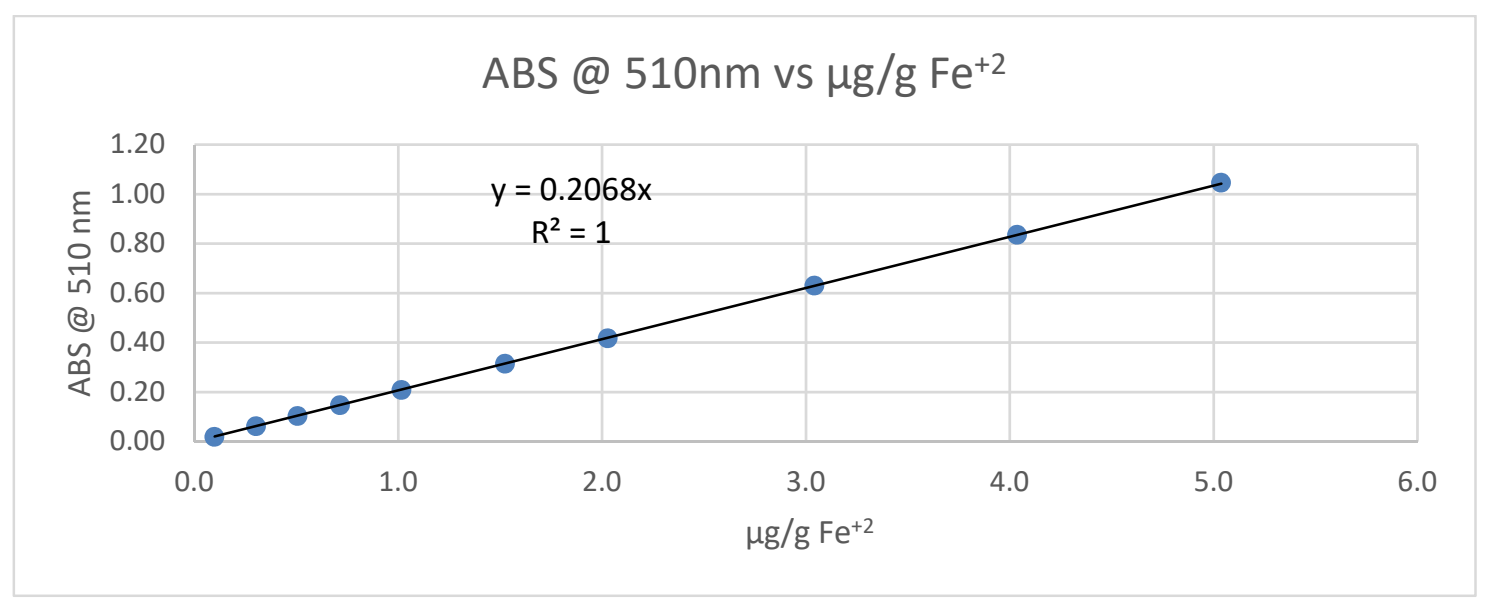

FIGURE 1 Absorbance at $510 \mathrm{~nm}$ versus $\mathrm{Fe}^{+2}$ concentrations. 


\subsection{VAN DE GRAAFF OPERATION AND OXALIC ACID DOSIMETRY}

The low-energy ( $3 \mathrm{MeV}$ ) Van de Graaff accelerator provides the capability of delivering high levels of electron/photon dose rates without creating activation and handling hazards for the irradiated materials. To determine the dependence of beam parameters and the dose delivered to the sample, an oxalic acid dosimeter was used. The dose was determined by comparing the concentration of oxalic acid prior to and after irradiation as the acid decomposed with irradiation [8].

$$
\begin{aligned}
\mathrm{O}_{2}+\mathrm{H} & \rightleftharpoons \mathrm{HO}_{2} \\
\mathrm{COOH}+\mathrm{HO}_{2} & \rightleftharpoons \mathrm{H}_{2} \mathrm{O}_{2}+\mathrm{CO}_{2} \\
\mathrm{HO}_{2}+\mathrm{HO}_{2} & \rightleftharpoons \mathrm{H}_{2} \mathrm{O}_{2}+\mathrm{O}_{2} \\
(\mathrm{COOH})_{2}+\mathrm{H} & \rightleftharpoons \mathrm{H}_{2} \mathrm{O}+\mathrm{CO}_{2}+\mathrm{CHO}
\end{aligned}
$$

Irradiated oxalic acid solution was titrated with $\mathrm{NaOH}$ to determine the amount of oxalic acid remaining. Once the concentration of acid was determined, the dose could be calculated from the following [8]:

$$
\log (D)=a \log (C)+b
$$

where $\mathrm{D}=$ absorbed dose in $\mathrm{eV} / \mathrm{mL} ; \mathrm{C}=$ the number of oxalic acid molecules decomposed in $1 \mathrm{~mL}$ sample; and $\mathrm{a}$ and $\mathrm{b}$ are constants depending on the initial concentration of oxalic acid and the number of moles of oxalic acid decomposed [8].

Figure 2 shows oxalic acid dosimetry results obtained for this set of experiments using a $1 \mathrm{~mL}$ sample volume, where the $\mathrm{y}$ axis represents dose (Mrad) and the $\mathrm{x}$ axis the Van de Graaff current $(\mu \mathrm{A})$. The dose delivered to sample is calculated using equation 11

$$
\text { Mrad }=\text { Slope } \times \mu \mathrm{A} \times \text { Time Interval (min) }
$$




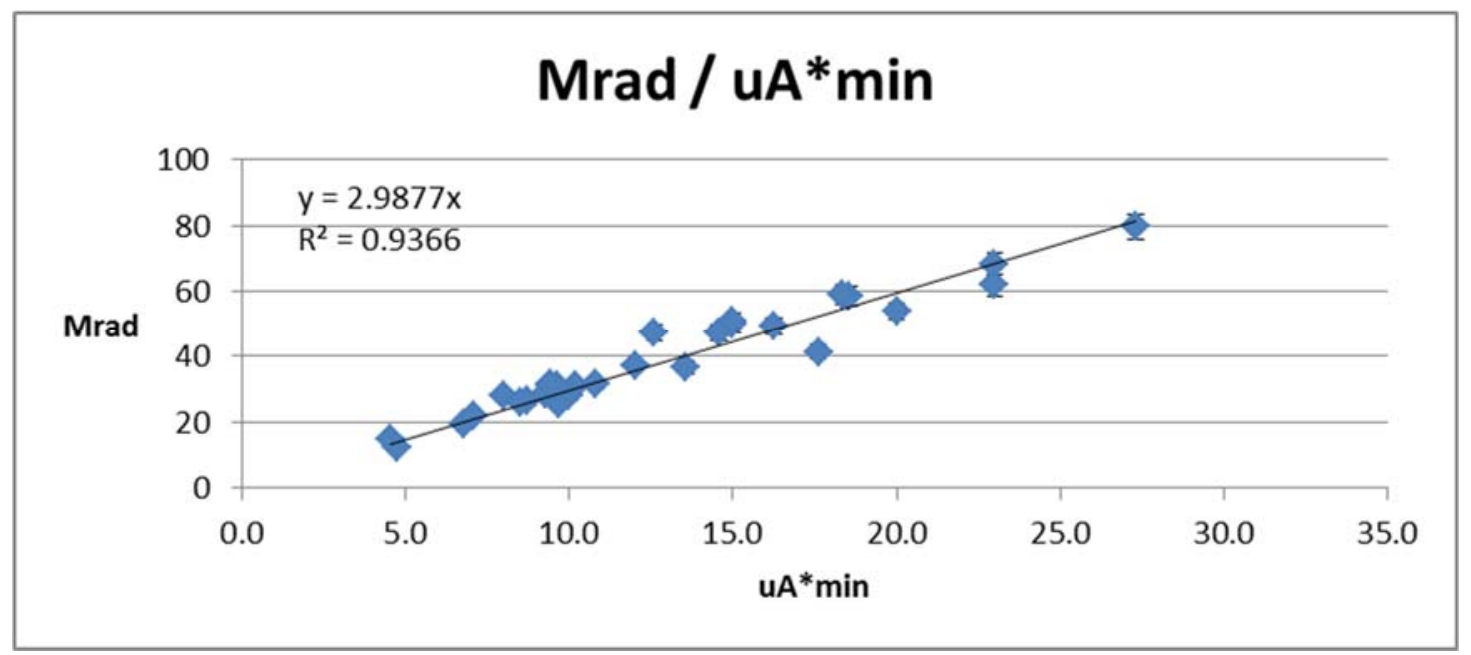

FIGURE 2 Dependence of dose vs. Van de Graaff irradiation parameters for a $1.0 \mathrm{~mL}$ sample.

The Van de Graaff beam can be used in pulse mode or direct current (DC) mode, with pulse widths of 5, 12, 25, 55, and 100 nanoseconds and a variable pulse-width feature. The frequency is adjustable from 1 to $720 \mathrm{~Hz}$. A majority of experiments were performed in the pulse mode of operation; however, one sample was irradiated in the DC mode to see if the different beam mode could affect precipitation of uranium solution. Samples were irradiated in a sample holder mounted directly in front of the beam window.

\subsection{TEMPERATURE MEASUREMENTS}

The sample was temperature controlled using a water bath that circulates around the sample holder. Since sample temperatures varied as a function of beam current, temperature measurements were conducted for different Van de Graaff beam currents and water bath temperature settings. Figure 3 shows the difference in temperature of a $1 \mathrm{~mL}$ sample during the irradiation at different beam currents. Since the presence of the thermocouple could interfere with actual irradiation of the LEU solution, Equation 12 was used to determine the sample temperature for irradiation of LEU samples.

$$
y=2.269 x+\text { Bath Temperature }
$$




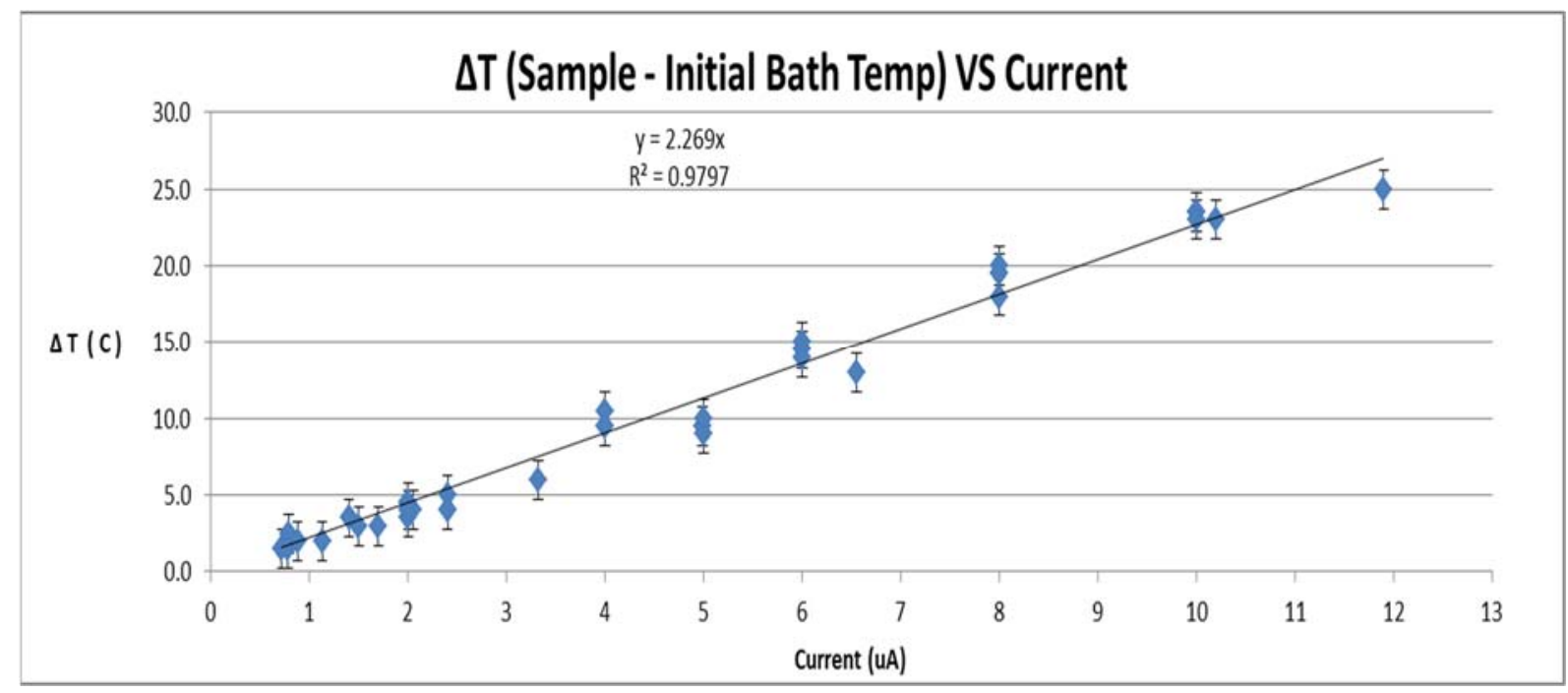

FIGURE $3 \Delta \mathrm{T}\left({ }^{\circ} \mathrm{C}\right)$ versus Van de Graaff current $(\mu \mathrm{A})$.

\subsection{EXPERIMENTAL DESIGN}

Figure 4 shows a flow diagram of the experiment, and Figure 5 shows the enclosure with the experimental setup at the end of the Van de Graaff beamline. A helium/argon cylinder provided a sweep gas for the experiment. A calibrated OMEGA ${ }^{\circledR}$ FMA 5400-ST mass flow controller was used to control the flow of the sweep gas. A calibrated OMEGA MMA030V10H4C0T3A5CE pressure transducer was used to monitor the pressure at the outlet of the sweep gas. Sweep gas was introduced via stainless steel tubing to the inlet of a quartz vial containing the uranyl sulfate solution. The vial was located inside a water-cooled stainless steel sample holder at the end of the Van de Graaff beamline. Stainless steel tubing was connected to the outlet of the vial to a Pfeiffer OmniStar ${ }^{\mathrm{TM}}$ GSD320 gas analyzer equipped with a 1-200 amu PrismaPlus $^{\mathrm{TM}}$ QMG220 mass spectrometer. 


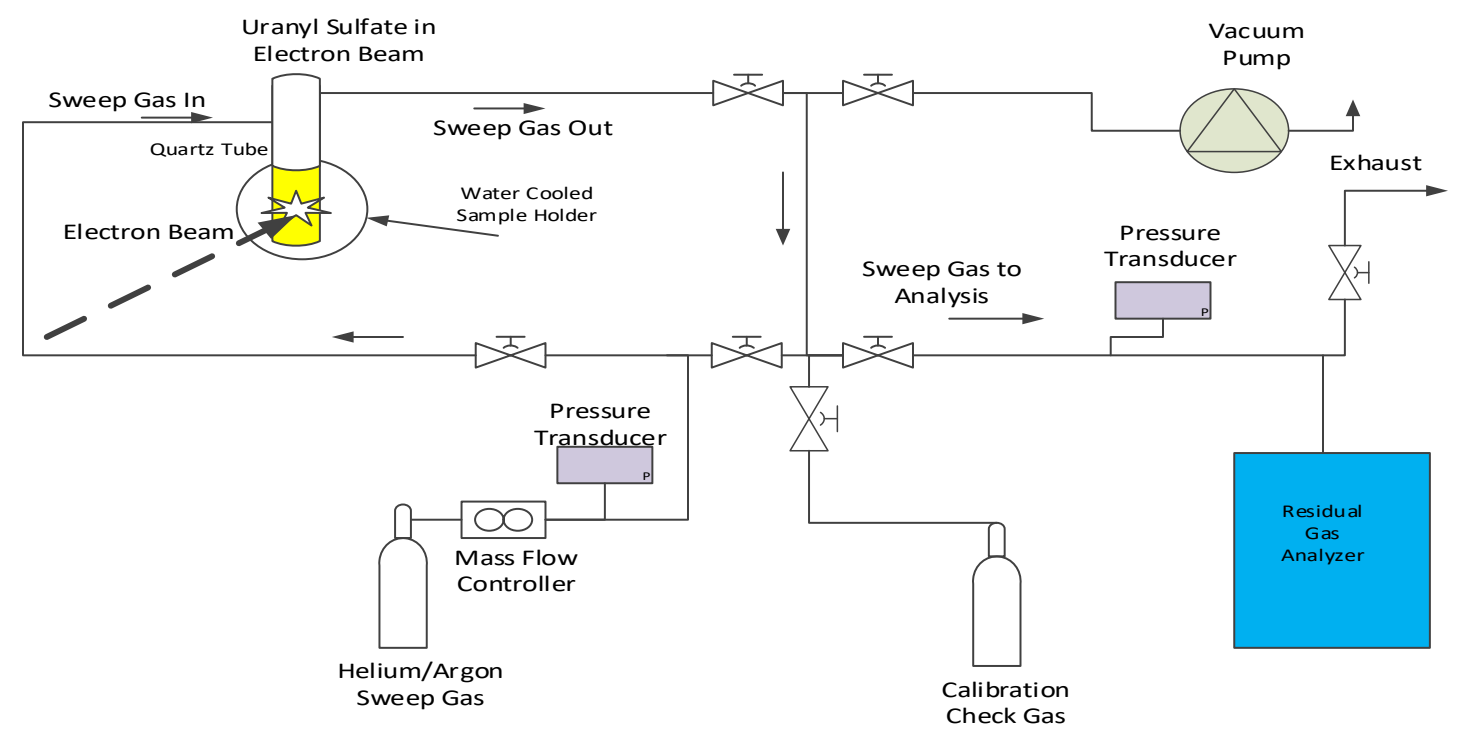

FIGURE 4 Diagram of the irradiation setup.

Before each irradiation, a quartz tube containing $1 \mathrm{~mL}$ of uranyl sulfate solution was inserted into a water-cooled window located at the end of the Van de Graaff beamline.

Headspace of the vial containing the LEU sample was purged with the He/Ar sweep gas. The chiller was set to the desired temperature, and the $3 \mathrm{MeV}$ electron beam was set to the desired current. The sample was irradiated with the electron beam for a predetermined length of time. The generated hydrogen and oxygen were monitored using the gas analyzer, which samples a small portion of the gas.

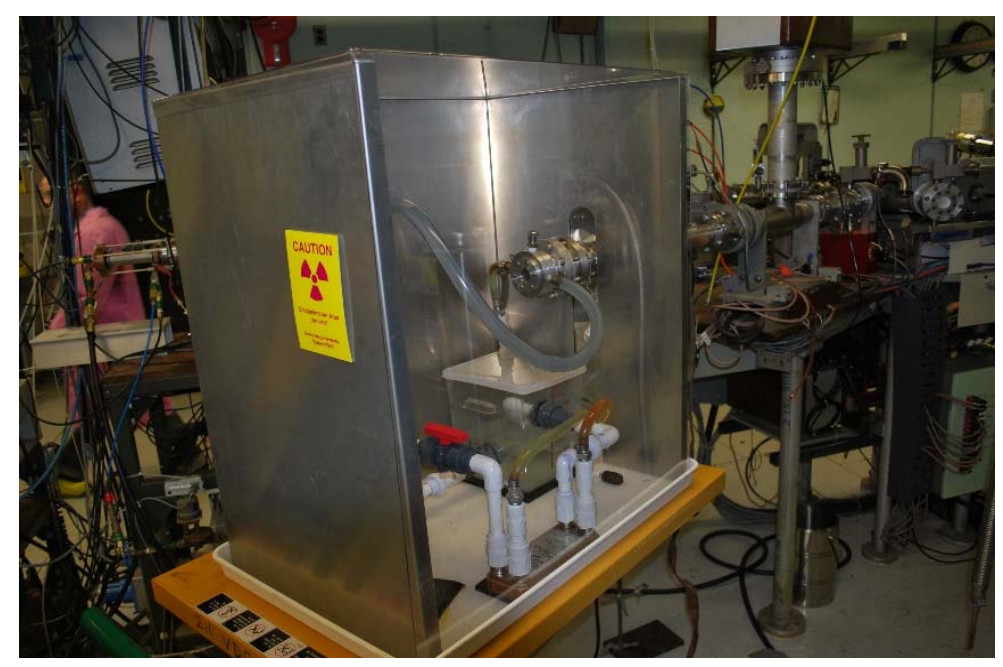

FIGURE 5 Photograph of the irradiation setup at the Van de Graaff accelerator facility. 


\subsection{GAS DATA ANALYSIS}

Gases that were dissolved in solution were not analyzed. The solution was not continuously purged during irradiation to release the dissolved gases. A single-point calibration standard introduced at the sampling pressure was used to calibrate the analyzer. Argon at $0.499 \%$ was used as an internal standard. Calibration standards were purchased from the vendor with an uncertainty of $\pm 2 \%$. Reported uncertainties for concentrations of hydrogen and oxygen were within $10 \%$. Equation 13 was used to generate a response factor $(\mathrm{RF})$ for each analyte. It is based on the ion current ( $\mathrm{IC}_{\text {analyte}}$ ) and concentration of the analyte and the ion current $\left(\mathrm{IC}_{\mathrm{is}}\right)$ and concentration of the internal standard (IS). The analyte concentration during experiments was determined using Equation 14. Calibration by this method made the analysis independent of sample pressure and detector instability. Background levels of nitrogen, oxygen, and hydrogen were determined from the blank value and subtracted from the data. Oxygen values reported were corrected by subtracting a value based on the amount of nitrogen detected relative to the ratio of nitrogen to oxygen in air (0.2683) using Equation 15.

$$
\begin{gathered}
\mathrm{RF}=\mathrm{IC}_{\text {analyte }} \times[\mathrm{IS}] / \mathrm{IC}_{\mathrm{IS}} \times[\% \text { Analyte }] \\
{[\% \text { Analyte }]=\mathrm{IC}_{\text {analyte }} \times[\mathrm{IS}] / \mathrm{IC} \text { Is } \times \mathrm{RF}} \\
{[\% \text { Oxygen Corrected }]=[\% \text { Oxygen }]-[\% \text { Nitrogen }] \times 0.2683}
\end{gathered}
$$

After the concentration of each gas was determined, the total $\mu$ moles of each analyte was calculated using the concentration data. The system was a once-through system with the $\mathrm{He} / \mathrm{Ar}$ sweep gas flowing at a constant rate set by the mass flow controller. The pressure and temperature at the analyzer were kept constant during the experiment. The relationship between the volume of gas flowing through the system and the analysis time was used to determine the $\mu$ moles of gas generated throughout the experiment and the total generated. The ideal gas law equation was used to find the $\mu$ moles of gas detected, which was summed over the entire experiment for the total using Equation 16.

$$
\mu \mathrm{m}=[\mathrm{PV} / \mathrm{RT}] \times[\% \text { Analyte } / 100] \times 10^{6}
$$

where: $\mu \mathrm{m}=\mu$ moles, $\mathrm{R}=$ gas constant, $\mathrm{T}=$ analysis temperature, $\mathrm{P}=$ analysis pressure, and $\mathrm{V}=$ gas flow $\times$ time interval. 


\section{RESULTS AND DISCUSSION}

\section{1 $\mathrm{Fe}^{+2}$ ANALYSIS}

Initially, samples were taken for color development within 30 minutes after an irradiation. The samples would then be analyzed at a later date, since the method produces a colored solution that is stable for up to six months. This, however, proved to be problematic, as it was shown that due to presence of peroxide in the samples post irradiation, the redox reactions in the irradiated samples were affecting the concentration of $\mathrm{Fe}^{+2} / \mathrm{Fe}^{+3}$. Another potential analytical problem was seen during the analysis of unirradiated LEU samples spiked with $\mathrm{Fe}^{+3}$. It was determined that all $\mathrm{Fe}^{+3}$ added to an unirradiated sample of LEU solution turned to $\mathrm{Fe}^{+2}$. This could be due to some presence of $\mathrm{U}^{+4}$ that could affect the oxidation state of $\mathrm{Fe}$ and interfere with the measurement of $\mathrm{Fe}^{+2} / \mathrm{Fe}^{+3}$ caused by irradiation. Equation 17 shows that uranium could donate an electron to the weakly bound $2 \mathrm{Fe}^{+3}$ (Phen) complex, thus reducing it to the +2 state [9] There are other metal ion interferences using this method.

$$
\mathrm{U}(\mathrm{IV})+2(\mathrm{Fe}(\mathrm{III})) \text { Phen } \rightarrow \mathrm{U}(\mathrm{VI})+2(\mathrm{Fe}(\mathrm{II})) \text { Phen }
$$

While the $\mathrm{Fe}^{+2}$ spike was primarily standard grade (99.99\%) purity, the $\mathrm{Fe}^{+3}$ spiking solution had a purity of $96 \%$ and had other metal ion contaminants. Without better understanding of how the presence of $\mathrm{U}^{+4}$ or other impurities affects the distribution of $\mathrm{Fe}^{+2} / \mathrm{Fe}^{+3}$, we cannot assign the changes in Fe oxidation states solely to redox reactions caused by radiolysis during the irradiation.

Table 1 shows the impurities in LEU solution detected using ICP-MS (inductively coupled plasma mass spectrometry). Concentrations are reported with $\pm 10 \%$ uncertainties. Concentration of $\mathrm{Fe}$ was analyzed using the 1,10-phenathroline method after heating the sample in the presence of hydroxylamine hydrochloride to reduce $\mathrm{Fe}^{+3}$ to $\mathrm{Fe}^{+2}$ state.

TABLE 1 LEU Solution ICP-MS analysis. *Fe analyzed using the phenanthroline method.

\begin{tabular}{cccccccccc}
\hline $\begin{array}{c}\text { Uranium } \\
\begin{array}{c}\text { Concentration, } \\
\mathrm{gU} / \mathrm{L} \text { solution }\end{array}\end{array}$ & $\begin{array}{c}\mathrm{Cr} \\
\mathrm{mg} / \mathrm{L}\end{array}$ & $\begin{array}{c}\mathrm{Mn} \\
\mathrm{mg} / \mathrm{L}\end{array}$ & $\begin{array}{c}* \mathrm{Fe} \\
\mathrm{mg} / \mathrm{L}\end{array}$ & $\begin{array}{c}\mathrm{Co} \\
\mathrm{mg} / \mathrm{L}\end{array}$ & $\begin{array}{c}\mathrm{Ni} \\
\mathrm{mg} / \mathrm{L}\end{array}$ & $\begin{array}{c}\mathrm{Cu} \\
\mathrm{mg} / \mathrm{L}\end{array}$ & $\begin{array}{c}\mathrm{Zn} \\
\mathrm{mg} / \mathrm{L}\end{array}$ & $\begin{array}{c}\mathrm{Cd} \\
\mathrm{mg} / \mathrm{L}\end{array}$ & $\begin{array}{c}\mathrm{Pt} \\
\mathrm{mg} / \mathrm{L}\end{array}$ \\
\hline 193.730 & $<1.57$ & $<1.00$ & 11 & $<0.19$ & $<1.43$ & $<0.79$ & $<3.71$ & $<0.19$ & $<0.11$ \\
\hline
\end{tabular}

\subsection{IRRADIATIONS TO DETERMINE THE EXPERIMENTAL PARAMETERS FOR PRECIPITATION}

Table 2 shows the results of the irradiations of LEU solution at $\sim 194 \mathrm{gU} / \mathrm{L}$. The initial irradiations were performed to determine the base parameters of the accelerator current and temperature at which precipitation occurred. None of the samples showed signs of precipitate during or immediately after the irradiation. Uranium precipitate was observed only about 24 hours after the irradiation. Figure 6 shows a photograph of uranium samples with and without 
precipitate. Samples at 2.5 and $5 \mu \mathrm{A}$ current never showed signs of precipitation. Following the initial tests at lower current, irradiation using a current of $10 \mu \mathrm{A}$ and a temperature of about $33^{\circ} \mathrm{C}$ was performed.

After testing all irradiated samples for peroxide, all samples tested positive immediately after irradiation; however, the exact concentration of peroxide could not be determined due to the change of indicator color from blue to green (i.e., the presence of uranium), as discussed previously.

The results listed below are from a reanalysis of the samples except for irradiation at $2.5 \mu \mathrm{A}$ performed on $6 / 14$. There was not enough sample to repeat the analysis, so the results reported are from a sampling immediately after the irradiation. $\mathrm{No} \mathrm{Fe}^{+2}$ was detected immediately after the irradiation.

Another disagreement with the rest of the results is for the irradiation performed on $6 / 17$ at a

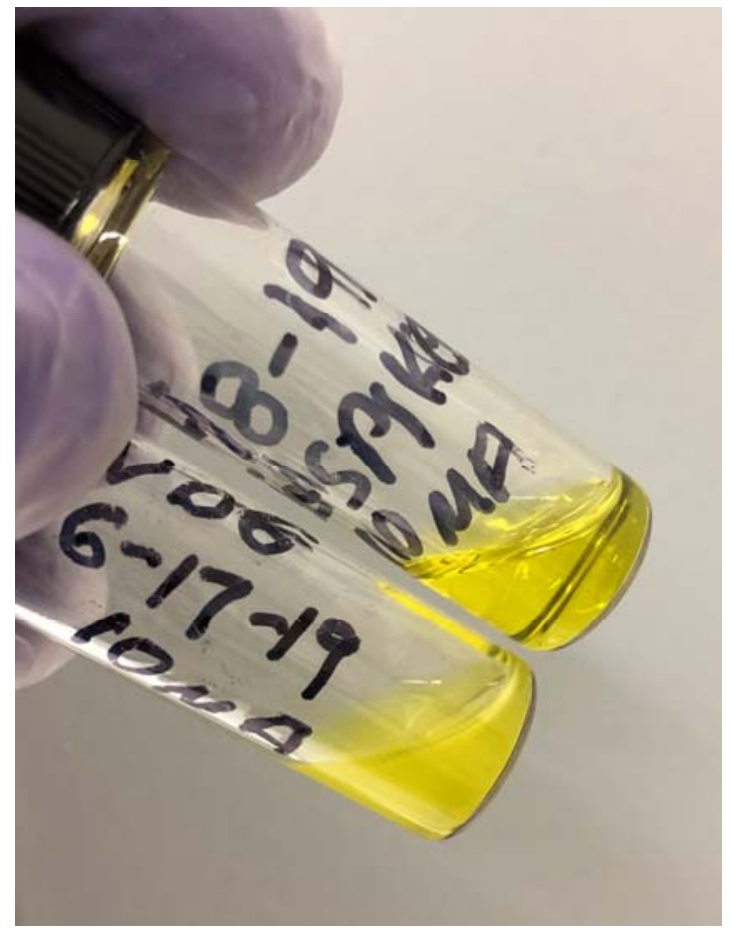

FIGURE 6 Irradiated LEU sample containing $U$ precipitate (bottom) and containing no $\mathrm{U}$ precipitate (top). $10 \mu \mathrm{A}$ current, where there was about a 50:50 split between the $\mathrm{Fe}^{+2}$ and $\mathrm{Fe}^{+3}$ distributions. When initially analyzed immediately after irradiating, the $\mathrm{Fe}^{+2}$ was at $2 \mu \mathrm{g} / \mathrm{g}$. The analysis performed later showed $4.6 \mu \mathrm{g} / \mathrm{g}$, with no appreciable $\mathrm{pH}$ changes.

Gas generation rates listed as $\mu$ moles/min were similar to those of irradiations performed in the past [5].

\subsection{IRRADIATIONS OF $\mathrm{Fe}^{+2}$ SPIKED SAMPLES}

Table 3 shows the data from unirradiated and irradiated samples of LEU spiked with $\mathrm{Fe}^{+2}$ at $169 \mu \mathrm{g} / \mathrm{g}$. None of these LEU samples showed signs of precipitation during or after the irradiation. Comparing the samples irradiated for 240, 60, and 30 minutes, all tested positive for peroxide immediately after the irradiation. Figures 7 and 8 show pictures of the peroxide test strips immediately after irradiations. The photograph of the peroxide strip for sample irradiated on 7/2/19 without added Fe (Figure 7) indicates a higher concentration of peroxide than the sample with added $\mathrm{Fe}$ (Figure 8). This indicates that the presence of Fe affects the final concentration of peroxide that ultimately prevents precipitation of uranium. No appreciable $\mathrm{pH}$ changes were observed. The final $\mathrm{Fe}^{+2}$ concentrations were similar, showing no particular trend for different irradiation times between 30 and 240 minutes. The reporting limit for samples was about $5 \mu \mathrm{g} / \mathrm{g}$, and the final concentration of $\mathrm{Fe}^{+2}$ was higher than that of $\mathrm{Fe}^{+3}$. 
TABLE 2 Irradiation parameters and analysis data for LEU samples without added Fe spike

\begin{tabular}{|c|c|c|c|c|c|c|c|c|c|c|}
\hline Description & $\begin{array}{c}\text { Van de Graaff } \\
\text { Mode }\end{array}$ & Date & $\begin{array}{c}\mathrm{LEU} \\
(\mathrm{gU} / \mathrm{L})\end{array}$ & $\begin{array}{l}\text { Sample } \\
\text { Temp. } \\
\left({ }^{\circ} \mathrm{C}\right)\end{array}$ & $\begin{array}{c}\text { Average } \\
\text { Current } \\
(\mu \mathrm{A})\end{array}$ & $\begin{array}{c}\text { Irradiation } \\
\text { Time } \\
(\mathrm{min}) \\
\end{array}$ & $\begin{array}{c}\text { Total Dose } \\
\text { (Mrad) }\end{array}$ & $\begin{array}{c}\mathrm{O}_{2} \\
(\mu \mathrm{M} / \mathrm{min})\end{array}$ & $\begin{array}{c}\mathrm{H}_{2} \\
(\mu \mathrm{M} / \mathrm{min})\end{array}$ & $\begin{array}{c}\text { Pre-irradiation } \\
\text { Total Fe } \\
(\mu \mathrm{g} / \mathrm{g})\end{array}$ \\
\hline $\begin{array}{l}\text { LEU } \\
194 \mathrm{gU} / \mathrm{L}\end{array}$ & Not Irradiated & & 194 & & & & & & & 8.7 \\
\hline $\begin{array}{l}\text { LEU_PPT Test } \\
2.5 \mu \mathrm{A}\end{array}$ & Pulsed & $6 / 14 / 19$ & 194 & 26 & 2.5 & 229 & 1710 & 0.292 & 0.670 & 8.7 \\
\hline $\begin{array}{l}\text { LEU_PPT Test } \\
10 \mu \mathrm{A}\end{array}$ & Pulsed & $6 / 17 / 19$ & 194 & 31 & 9.9 & 240 & 7090 & 0.980 & 2.182 & 8.7 \\
\hline $\begin{array}{l}\text { LEU_PPT Test } \\
20 \mu \overline{\mathrm{A}}\end{array}$ & Pulsed & $6 / 19 / 19$ & 194 & 58 & 21.0 & 147 & 9200 & 1.042 & 2.359 & 8.7 \\
\hline $\begin{array}{l}\text { LEU_PPT Test } \\
15 \mu \overline{\mathrm{A}}\end{array}$ & Pulsed & $6 / 25 / 19$ & 194 & 42 & 14.6 & 240 & 10400 & 0.977 & 2.174 & 8.7 \\
\hline $\begin{array}{l}\text { Re-Test of } \\
20 \mu \mathrm{A}\end{array}$ & Pulsed & $6 / 27 / 19$ & 194 & 55 & 19.8 & 356 & 21000 & 1.136 & 2.622 & 8.7 \\
\hline $\begin{array}{l}\text { DC vs Pulsed } \\
10 \mu \mathrm{A}\end{array}$ & Direct Current & $7 / 2 / 19$ & 194 & 32 & 9.7 & 240 & 6920 & 0.852 & 1.967 & 8.7 \\
\hline $\begin{array}{l}\text { PPT Test } \\
5 \mu \mathrm{A}\end{array}$ & Pulsed & $7 / 10 / 19$ & 194 & 30 & 5.2 & 240 & 3710 & 0.666 & 1.522 & 8.7 \\
\hline Description & $\begin{array}{c}\text { Van de Graaff } \\
\text { Mode }\end{array}$ & Date & $\begin{array}{c}\text { FINAL Fe } \\
(\mu \mathrm{g} / \mathrm{g})\end{array}$ & $\begin{array}{c}\text { FINAL Fe } \\
(\mu \mathrm{g} / \mathrm{g})\end{array}$ & Final $\mathrm{pH}$ & $\begin{array}{c}\text { Precipit. } \\
\text { DURING } \\
\text { Irradiation } \\
\end{array}$ & $\begin{array}{l}\text { Precipit. } \\
\text { AFTER } \\
\text { Irradiation } \\
\end{array}$ & $\begin{array}{c}\mathrm{H}_{2} \mathrm{O}_{2} \text { Test } \\
\text { Strip } \\
\end{array}$ & $\begin{array}{c}\text { Precipit. } \\
\text { Re-dissolved }\end{array}$ & \\
\hline $\begin{array}{l}\text { LEU } \\
194 \mathrm{gU} / \mathrm{L}\end{array}$ & Not Irradiated & & & & 1.05 & & & & & \\
\hline $\begin{array}{l}\text { LEU_PPT Test } \\
2.5 \mu \mathrm{A}\end{array}$ & Pulsed & $6 / 14 / 19$ & $<0.8$ & 8.5 & N.A. & No & NO & N.A. & & \\
\hline $\begin{array}{l}\text { LEU_PPT Test } \\
10 \mu \overline{\mathrm{A}}\end{array}$ & Pulsed & $6 / 17 / 19$ & 4.6 & 4.1 & 1.01 & No & Yes & N.A. & Yes & \\
\hline $\begin{array}{l}\text { LEU_PPT Test } \\
20 \mu \overline{\mathrm{A}}\end{array}$ & Pulsed & $6 / 19 / 19$ & 9.3 & $<0.8$ & 1.06 & No & Yes & N.A. & Yes & \\
\hline $\begin{array}{l}\text { LEU_PPT Test } \\
15 \mu \overline{\mathrm{A}}\end{array}$ & Pulsed & $6 / 25 / 19$ & 9.1 & $<0.8$ & 1.07 & No & Yes & Positive & Yes & \\
\hline $\begin{array}{l}\text { Re-Test of } \\
20 \mu \mathrm{A}\end{array}$ & Pulsed & $6 / 27 / 19$ & 8.8 & $<0.8$ & 1.00 & No & Yes & Positive & Yes & \\
\hline $\begin{array}{l}\text { DC vs Pulsed } \\
10 \mu \mathrm{A}\end{array}$ & Direct Current & $7 / 2 / 19$ & 9.3 & $<0.8$ & 1.08 & No & Yes & Positive & Yes & \\
\hline $\begin{array}{l}\text { PPT Test } \\
5 \mu \mathrm{A}\end{array}$ & Pulsed & $7 / 10 / 19$ & 8.9 & $<0.8$ & 1.05 & No & No & Positive & & \\
\hline
\end{tabular}


TABLE 3 Irradiation parameters and analysis data for $\mathrm{LEU}$ samples with added $\mathrm{Fe}^{+2}$ spike

\begin{tabular}{|c|c|c|c|c|c|c|c|c|c|}
\hline Description & $\begin{array}{l}\text { Van de } \\
\text { Graaff } \\
\text { Mode }\end{array}$ & Date & $\begin{array}{c}\text { LEU } \\
(\mathrm{gU} / \mathrm{L})\end{array}$ & $\begin{array}{l}\text { Sample } \\
\text { Temp. } \\
\left({ }^{\circ} \mathrm{C}\right)\end{array}$ & $\begin{array}{c}\text { Average } \\
\text { Current } \\
(\mu \mathrm{A})\end{array}$ & $\begin{array}{l}\text { Irradiation } \\
\text { Time } \\
(\mathrm{min}) \\
\end{array}$ & $\begin{array}{c}\text { Total Dose } \\
(\mathrm{Mrad})\end{array}$ & $\begin{array}{c}\mathrm{O}_{2} \\
(\mu \mathrm{M} / \mathrm{min})\end{array}$ & $\begin{array}{c}\mathrm{H}_{2} \\
(\mu \mathrm{M} / \mathrm{min})\end{array}$ \\
\hline $\mathrm{Fe}^{+2}$ Spiked LEU & $\begin{array}{c}\text { Not } \\
\text { Irradiated }\end{array}$ & & 190 & & & & & & \\
\hline $\begin{array}{l}\mathrm{Fe}^{+2} \text { Spiked } \\
\text { LEU_PPT Test } \\
10 \mu \overline{\mathrm{A}}\end{array}$ & Pulsed & $7 / 18 / 19$ & 190 & 33 & 10 & 240 & 7110 & 0.430 & 0.997 \\
\hline $\begin{array}{l}\mathrm{Fe}^{+2} \text { Spiked } \\
\text { LEU_Total Dose }\end{array}$ & Pulsed & $7 / 19 / 19$ & 190 & 33 & 10 & 60 & 1810 & 0.399 & 1.044 \\
\hline 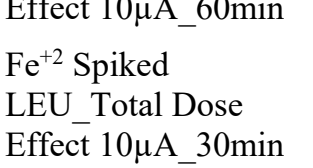 & Pulsed & $7 / 19 / 19$ & 190 & 33 & 10 & 30 & 914 & 0.353 & 1.047 \\
\hline $\mathrm{Fe}^{+2}$ Spiked BLANK & Pulsed & $7 / 23 / 19$ & & 33 & 10 & 63 & 1920 & 0.723 & 1.747 \\
\hline Description & $\begin{array}{l}\text { Van de } \\
\text { Graaff } \\
\text { Mode }\end{array}$ & Date & $\begin{array}{l}\text { Pre-irradiation } \\
\text { Total Fe } \\
(\mu \mathrm{g} / \mathrm{g})\end{array}$ & $\begin{array}{c}\text { FINAL Fe }^{+2} \\
(\mu \mathrm{g} / \mathrm{g})\end{array}$ & $\begin{array}{c}\text { FINAL Fe }^{+3} \\
(\mu \mathrm{g} / \mathrm{g})\end{array}$ & Final pH & $\begin{array}{l}\text { Precipitation } \\
\text { DURING } \\
\text { Irradiation }\end{array}$ & $\begin{array}{l}\text { Precipitation } \\
\text { AFTER } \\
\text { Irradiation }\end{array}$ & $\begin{array}{c}\mathrm{H}_{2} \mathrm{O}_{2} \text { Test } \\
\text { Strip }\end{array}$ \\
\hline $\mathrm{Fe}^{+2}$ Spiked LEU & $\begin{array}{c}\text { Not } \\
\text { Irradiated }\end{array}$ & & 169 & & & 1.06 & & & \\
\hline $\begin{array}{l}\mathrm{Fe}^{+2} \text { Spiked } \\
\text { LEU_PPT Test } \\
10 \mu \overline{\mathrm{A}}\end{array}$ & Pulsed & $7 / 18 / 19$ & 169 & 97 & 71 & 1.06 & No & No & Positive \\
\hline $\begin{array}{l}\mathrm{Fe}^{+2} \text { Spiked } \\
\text { LEU_Total Dose } \\
\text { Effect } 10 \mu \mathrm{A} \text { 60 min }\end{array}$ & Pulsed & $7 / 19 / 19$ & 169 & 93 & 75 & 1.07 & No & No & Positive \\
\hline $\begin{array}{l}\mathrm{Fe}^{+2} \text { Spiked } \\
\text { LEU_Total Dose } \\
\text { Effect } 10 \mu \mathrm{A} \text { A_30min }\end{array}$ & Pulsed & $7 / 19 / 19$ & 169 & 100 & 68 & 1.04 & No & No & Positive \\
\hline $\mathrm{Fe}^{+2}$ Spiked BLANK & Pulsed & $7 / 23 / 19$ & 205 & 42 & 164 & N.A. & No & No & Positive \\
\hline
\end{tabular}

N.A. indicates sample was not analyzed. 


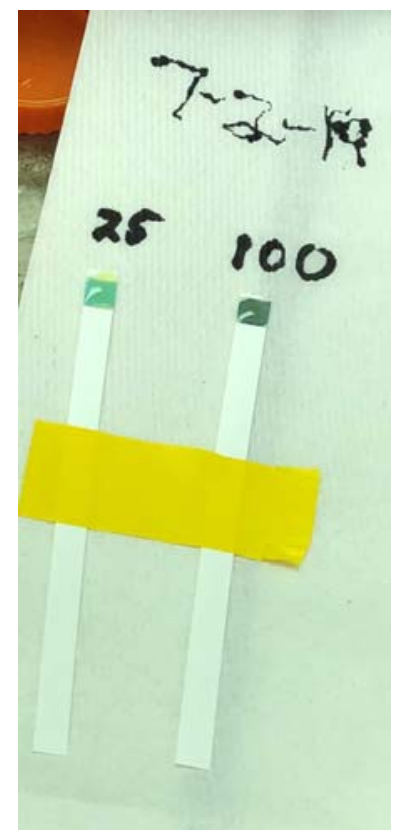

FIGURE 7 Peroxide test of un-spiked sample from $7 / 2 / 19$, 240 minute irradiation at $10 \mu \mathrm{A}$ direct current.

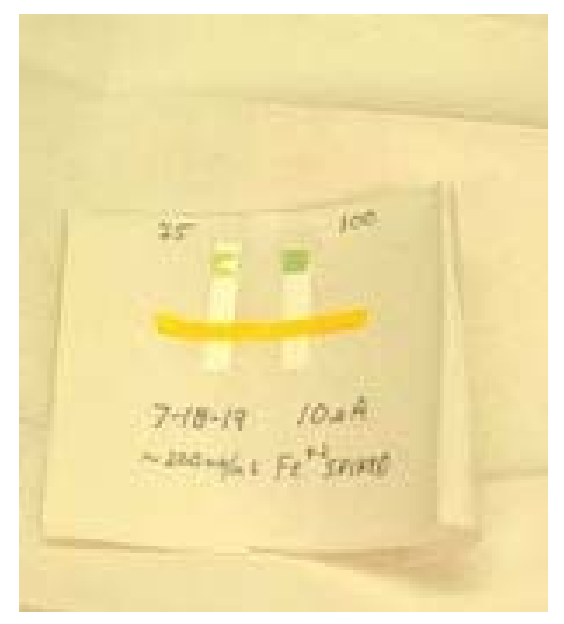

FIGURE 8 Peroxide test of $\mathrm{Fe}^{+2}$ spiked sample from 7/18/19, 240 minute irradiation at $10 \mu \mathrm{A}$.

\subsection{IRRADIATIONS OF $\mathrm{Fe}^{+3}$ SPIKED SAMPLES}

Table 4 shows the data from un-irradiated and irradiated samples of LEU spiked with $\mathrm{Fe}^{+3}$ at $170 \mu \mathrm{g} / \mathrm{g}$. None of these samples showed signs of precipitation during or after the irradiation. All irradiated samples tested positive for peroxide immediately after the irradiation. No appreciable $\mathrm{pH}$ changes were observed, and the gas generation rates were comparable to those of the $\mathrm{Fe}^{+2}$ spiked samples. The final $\mathrm{Fe}^{+2}$ concentrations were essentially the same, showing no particular trend between the different irradiation times. The reporting limit for samples was about $5 \mu \mathrm{g} / \mathrm{g}$, and final concentration of $\mathrm{Fe}^{+3}$ was higher than that of $\mathrm{Fe}^{+2}$. 
TABLE 4 Irradiation parameters and analysis data for $\mathrm{LEU}$ samples with added $\mathrm{Fe}^{+3}$ spike

\begin{tabular}{|c|c|c|c|c|c|c|c|c|c|}
\hline Description & $\begin{array}{l}\text { Van de Graaff } \\
\text { Mode }\end{array}$ & Date & $\begin{array}{c}\mathrm{LEU} \\
(\mathrm{gU} / \mathrm{L})\end{array}$ & $\begin{array}{l}\text { Sample } \\
\text { Temp. } \\
\left({ }^{\circ} \mathrm{C}\right)\end{array}$ & $\begin{array}{c}\text { Average } \\
\text { Current } \\
(\mu \mathrm{A})\end{array}$ & $\begin{array}{l}\text { Irradiation } \\
\text { Time } \\
\text { (min) } \\
\end{array}$ & $\begin{array}{l}\text { Total Dose } \\
\text { (Mrad) }\end{array}$ & $\begin{array}{c}\mathrm{O}_{2} \\
(\mu \mathrm{M} / \min )\end{array}$ & $\begin{array}{c}\mathrm{H}_{2} \\
(\mu \mathrm{M} / \mathrm{min}) \\
\end{array}$ \\
\hline $\mathrm{Fe}^{+3}$ Spiked LEU & Not Irradiated & & 190 & & & & & & \\
\hline $\begin{array}{l}\mathrm{Fe}^{+3} \text { Spiked } \\
\text { LEU_PPT Test } 10 \mu \mathrm{A}\end{array}$ & Pulsed & $7 / 25 / 19$ & 190 & 33 & 10 & 241 & 7340 & 0.465 & 0.979 \\
\hline $\begin{array}{l}\mathrm{Fe}^{+3} \text { Spiked } \\
\text { LEU_Total Dose } \\
\text { Effect } 10 \mu \mathrm{A} \_181 \mathrm{~min}\end{array}$ & Pulsed & $7 / 29 / 19$ & 190 & 33 & 10 & 181 & 5530 & 0.463 & 1.004 \\
\hline $\begin{array}{l}\mathrm{Fe}^{+3} \text { Spiked } \\
\text { LEU_Total Dose } \\
\text { Effect } 10 \mu \mathrm{A} \text { A_60min }\end{array}$ & Pulsed & $7 / 30 / 19$ & 190 & 33 & 10 & 60 & 1,800 & 0.341 & 0.713 \\
\hline $\begin{array}{l}\mathrm{Fe}^{+3} \text { Spiked } \\
\text { LEU_Total Dose } \\
\text { Effect 10 } 4 \text { A 30min }\end{array}$ & Pulsed & $7 / 30 / 19$ & 190 & 33 & 10 & 30 & 893 & 0.319 & 0.866 \\
\hline Description & $\begin{array}{c}\text { Van de Graaff } \\
\text { Mode }\end{array}$ & Date & $\begin{array}{c}\text { Pre-irradiation } \\
\text { Total Fe } \\
(\mu \mathrm{g} / \mathrm{g})\end{array}$ & $\begin{array}{c}\text { FINAL Fe }^{+2} \\
(\mu \mathrm{g} / \mathrm{g})\end{array}$ & $\begin{array}{c}\text { FINAL Fe }^{+3} \\
(\mu \mathrm{g} / \mathrm{g})\end{array}$ & Final $\mathrm{pH}$ & $\begin{array}{l}\text { Precipitation } \\
\text { DURING } \\
\text { Irradiation } \\
\end{array}$ & $\begin{array}{l}\text { Precipitation } \\
\text { AFTER } \\
\text { Irradiation } \\
\end{array}$ & $\begin{array}{l}\text { Hydrogen } \\
\text { Peroxide } \\
\text { Test Strip } \\
\end{array}$ \\
\hline $\mathrm{Fe}^{+3}$ Spiked LEU & Not Irradiated & & 170 & & & 1.06 & & & \\
\hline $\begin{array}{l}\mathrm{Fe}^{+3} \text { Spiked } \\
\text { LEU_PPT Test } 10 \mu \mathrm{A}\end{array}$ & Pulsed & $7 / 25 / 19$ & 170 & 70 & 100 & 1.04 & No & No & Positive \\
\hline $\begin{array}{l}\mathrm{Fe}^{+3} \text { Spiked } \\
\text { LEU_Total Dose } \\
\text { Effect } 10 \mu \text { A_181min }\end{array}$ & Pulsed & $7 / 29 / 19$ & 170 & 70 & 100 & 1.02 & No & No & Positive \\
\hline $\begin{array}{l}\mathrm{Fe}^{+3} \text { Spiked } \\
\text { LEU_Total Dose } \\
\text { Effect } 10 \mu \mathrm{A} \_60 \mathrm{~min}\end{array}$ & Pulsed & $7 / 30 / 19$ & 170 & 74 & 96 & 1.03 & No & No & Positive \\
\hline $\begin{array}{l}\mathrm{Fe}^{+3} \text { Spiked } \\
\text { LEU_Total Dose } \\
\text { Effect } 10 \mu \text { A__30min }\end{array}$ & Pulsed & $7 / 30 / 19$ & 170 & 74 & 96 & 1.04 & No & No & Positive \\
\hline
\end{tabular}

N.A. indicates sample was not analyzed. 


\subsection{SUMMARY OF RATIOS OF IRON OXIDATION STATES}

Table 5 shows a summary of the final ratios of $\mathrm{Fe}^{+3} / \mathrm{Fe}^{+2}$ for the $\mathrm{Fe}^{+2}$ and $\mathrm{Fe}^{+3}$ spiked LEU solutions. When the solution was spiked with $\mathrm{Fe}^{+2}$ or $\mathrm{Fe}^{+3}$, the preponderance of the final oxidation state favored the original oxidation state for these experiments. Although the irradiation times were limited to 240 minutes, the experiments indicate that the presence of $\mathrm{Fe}^{+3}$ oxidation state predominates after longer irradiation times.

TABLE 5 Final $\mathrm{Fe}^{+2} / \mathrm{Fe}^{+3}$ ratios for samples initially spiked with $\mathrm{Fe}^{+2}$ and $\mathrm{Fe}^{+3}$

\begin{tabular}{lccccc}
\hline Test Solution & $\begin{array}{c}\text { Total Dose } \\
(\mathrm{Mrad})\end{array}$ & $\mathrm{Fe}^{3+} / \mathrm{Fe}^{2+}$ & Test Solution & $\begin{array}{c}\text { Total Dose } \\
(\mathrm{Mrad})\end{array}$ & $\mathrm{Fe}^{2+} / \mathrm{Fe}^{3+}$ \\
\hline & & & & & \\
$\mathrm{Fe}^{2+}$ Spiked & 7110 & 0.74 & & 7340 & 0.69 \\
LEU & 1810 & 0.81 & $\mathrm{Fe}^{3+}$ Spiked & 5530 & 0.70 \\
& 914 & 0.68 & LEU & 1800 & 0.78 \\
& & & & 893 & 0.77 \\
\hline
\end{tabular}




\section{CONCLUSION}

Uranyl peroxide precipitates from a uranyl sulfate solution after bombardment with low LET particles (electron, gamma, x-rays). The precipitation process is a delayed phenomenon occurring within about 24 hours after bombardment. Hydrogen peroxide is detectable immediately after irradiation. Iron ions spiked into the solution prevent precipitation. When iron is spiked, there is reduced gas production $\left(\mathrm{H}_{2}\right.$ and $\left.\mathrm{O}_{2}\right)$ and hydrogen peroxide concentrations are reduced. The +2 or +3 oxidation states of iron appear to be equally effective at preventing precipitation, limiting gas production and reducing the post-irradiation hydrogen peroxide concentration. For these experiments, samples spiked with $\mathrm{Fe}^{+2}$ had more $\mathrm{Fe}^{+2}$ post-irradiation. Similarly, samples spiked with $\mathrm{Fe}^{+3}$ had more $\mathrm{Fe}^{+3}$ post irradiation. The data does indicate that with a longer irradiation time, the +3 oxidation state would be favored. 


\section{REFERENCES}

[1] Kalensky, M., Chemerisov, S., Youker, A., Hebden, A., Tkac, P., Makarashvili, V., Krahn, E., Krebs, J., Quigley, K., Lowe, R., Bowers, D., Niak, S., Graczyk, D., Sullivan, V., Bakel, A., and Vandegrift, G.F. "Radiolysis of Nitrate and Sulfate Solutions." ANL/CSE-13/23. November 20, 2012.

[2] Kalensky, M., Chemerisov, S., Youker, A., Tkac, P., Krebs, J., Quigley, K., Lowers, R., Bakel, A., and Vandegrift, G. F. "Means to Eliminate Uranyl Peroxide Precipitation in SHINE Target Solution.” ANL/CSE-13/21. March 14, 2013.

[3] Youker, A.J., Jerden, J., Kalensky, M., Quigley, K., Jonah, C., Chemerisov, S., and Vandegrift, G.F. "Peroxide Formation, Destruction, and Precipitation in Uranyl Sulfate Solutions: Simple Addition and Radiolytically Induced Formation." ANL/CSE-14/35. October 2014.

[4] Youker, A., Chemerisov, S., Tkac, P., Bowers, D., Kalensky, M., and Vandegrift, G.F. "A Solution-Based Approach for Mo-99 Production: Considerations for Nitrate versus Sulfate Media." Science and Technology of Nuclear Installations, Volume 2013, Article ID 402570, 10 pages.

[5] Kalensky, M., Chemerisov, S., Youker, A., Tkac, P., Krebs, J., Quigley, K., Lowers, R., Bakel, A.and George F. Vandegrift "Means to Eliminate Uranyl Peroxide Precipitation in SHINE Target Solution. Letter report, March 14, 2013

[6] Silverman, M.D., Watson, G.M., and McDuffie, H.F. "Peroxide Decomposition in Aqueous Homogeneous Reactor Fuels.” Industrial and Engineering Chemistry, 8, 1238-1241 (1956).

[7] American Public Health Association, American Water Works Association, Water Pollution Control Federation. "Standard Methods for the Examination of Water and Wastewater." $16^{\text {th }}$ Edition (1985).

[8] Draganic, I., "Oxalic Acid: The Only Aqueous Dosimeter for In-Pile Use," Nucleonics, 21(2), 33 (1963).

[9] Vydra, F., and Pribil, R. "Oxidation of Uranium ${ }^{\mathrm{IV}}$ with Iron iii in 1,10-Penanthroline Solutions: Indirect Colormetric Determination of Uranium.” Talanta, 9, 1009-1014 (1962). 



\section{Argonne $\mathbf{A}$}

\section{Chemical and Fuel Cycle Technologies Division}

Argonne National Laboratory

9700 South Cass Avenue, Bldg. 205

Argonne, IL 60439-4832

www.anl.gov 